\title{
Health Council: shortages critical
}

Canada needs to work faster to solve its critical shortage of physicians and other health care workers and other systemic problems, the Health Council of Canada says in its first report.

Canada also needs to work harder to bring health care closer to home for Aboriginal people, states the report and strengthen primary health care. Electronic patient records, which would reduce the amount of diagnositic t testing, is also long overdue.

Canada has invested "significant funds" to reform the system,

but the money is not providing immediate relief, Council Chair Michael Decter said when he released the report in late January. Solving human resource short- ages is key to achieving positive change, he said. The Council recommends that resource planning be focused on health care teams, and that students train on a team basis as well. The Council will host a National Human Health Resource summit in June .

"None of the reforms will succeed unless we have enough well-trained providers to run the system," Decter said.

As if to illustrate the report's findings, about 250 Ontario anesthesiologists held a 1-day meeting in Toronto on Feb. 11 in lieu of working, to publicize a shortage of about 90 anesthesiologists in the province. The job action closed operating rooms at 27 hospitals to all but essential surgeries on that day.

There are 450 vacancies for anesthesiologists across Canada, says Dr. Ren Mann, president of the Canadian Anesthesiologists' Society.

When Nova Scotia's premier expressed concern about the shortage, Health Minister Ujjal Dosanjh directed him to the federal $\$ 4.5$ billion Wait Times Reduction Fund. But that fund, which was to begin disbursing money this year, still requires legislative authority. Bill C-39, which will implement the fund, was tabled Feb. 7 but had not passed as of press time (Feb. 28), meaning that no money has yet been disbursed. - Laura Eggertson, CMAJ

\section{Humanitarian Aid}

\section{Relief needs coordination: CARE Canada}

Canada's nongovernmental organizations need a coordinated appeal process so they can raise funds with less administrative overhead, says CARE Canada's president and CEO.

John Watson says Canada should adopt a model similar to Britain's Disaster Emergency Committee. DEC coordinates $\approx$ national appeals, distributes money to organizations with the capacity to work in affected regions, and produces audited re$\stackrel{0}{\circ}$ ports on how funds are spent.

DEC has been very successful, says Watson. "It gets free

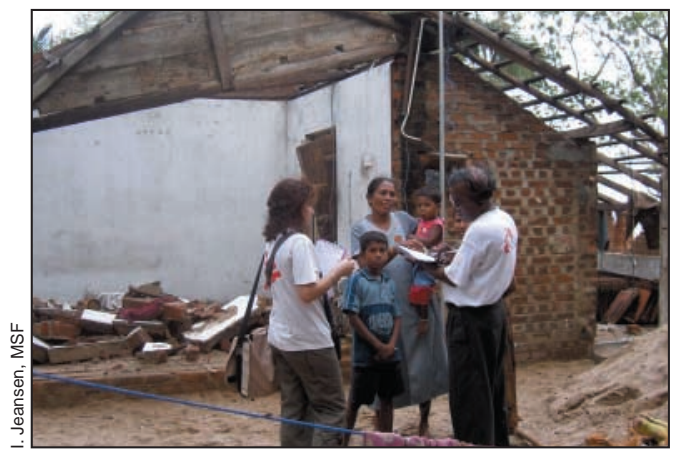

MSF, 1 of 5 UN-affiliated humanitarian agencies, sent staff to Sri Lanka to assess housing needs. media time, free bank services and allocates the resources according to a different breakdown for each emergency."

CARE Canada has written to its sister NGOs suggesting an outline for a joint appeal and asking for contributions to finance a study on how to set it up. Oxfam Canada and Save the Children have agreed to participate in the study.

"It's a long overdue idea," says Rieky Stuart, executive director of Oxfam Canada. The initiative should help donors who don't know how to choose among agencies.

The aim is to create the emergency committee before the next disaster. "Then you'll only see one appeal, and people will know [their donation] will be directed to the best profile of agencies active on the front line, and will be followed by an independent audit that will report back to donors," says Watson.

Watson applauds Ottawa's matching fund program for tsunami relief donations, but says NGOs should have organized themselves beforehand. The federal government approved matching donations to 27 different organizations, yet there are only $6-8$ agencies that specialize in professional humanitarian work internationally, Watson says.

"Humanitarian work is not something that can be done by happy amateurs. It requires a professional approach," Watson says. "Whenever there is a disaster, every organization under the sun sounds like it's got a role to play. Well, it's just not true."

The relief organizations need to be involved in preselecting agencies with experience, Watson says.

The number of volunteer agencies responding can overwhelm stricken countries. In late January, for example, there were 168 NGOs in Sri Lanka.

CARE Canada, OXFAM, World Vision, Médecins Sans Frontières and Save the Children are among those internationally affiliated agencies that the UN works with to provide humanitarian relief. - Laura Eggertson, CMAJ 